\title{
Use of adipose-derived stem cells in lymphatic tissue engineering and regeneration
}

\author{
Antonio Jorge Forte ${ }^{1,2}$, Daniel Boczar ${ }^{1}$, Rachel Sarabia-Estrada ${ }^{2}$, Maria T. Huayllani ${ }^{1}$, \\ Francisco R. Avila ${ }^{1}$, Ricardo A. Torres ${ }^{1}$, Gunel Guliyeva ${ }^{1}$, Thiha Aung ${ }^{3}$, \\ Alfredo Quiñones-Hinojosa ${ }^{2}$ \\ ${ }^{1}$ Division of Plastic Surgery and ${ }^{2}$ Department of Neurosurgery, Mayo Clinic, Jacksonville, FL, USA; ${ }^{3}$ Center of Plastic, Aesthetic, Hand, and \\ Reconstructive Surgery, University of Regensburg, Regensburg, Germany
}

The potential to differentiate into different cell lines, added to the easy and cost-effective method of extraction, makes adipose-derived stem cells (ADSCs) an object of interest in lymphedema treatment. Our study's goal was to conduct a comprehensive systematic review of the use of ADSCs in lymphatic tissue engineering and regeneration. On July 23, 2019, using PubMed/MEDLINE, Cochrane Clinical Answers, Cochrane Central Register of Controlled Trials, and Embase databases, we conducted a systematic review of published literature on the use of ADSCs in lymphatic tissue engineering and regeneration. There were no language or time frame limitations, and the following search strategy was applied: ((Adipose stem cell) OR Adipose-derived stem cell)) AND ((Lymphedema) OR Breast Cancer Lymphedema). Only original research manuscripts were included. Fourteen studies fulfilled the inclusion criteria. Eleven studies were experimental (in vitro or in vivo in animals), and only three were clinical. Publications on the topic demonstrated that ADSCs promote lymphangiogenesis, and its effect could be enhanced by modulation of vascular endothelial growth factor- $C$, interleukin- 7 , prospero homeobox protein 1 , and transforming growth factor- $\beta 1$. Pilot clinical studies included 11 patients with breast cancer-related lymphedema, and no significant side effects were present at 12-month follow-up. Literature on the use of ADSCs in lymphatic tissue engineering and regeneration demonstrated promising data. Clinical evidence is still in its infancy, but the scientific community agrees that ADSCs can be useful in regenerative lymphangiogenesis. Data collected in this review indicate that unprecedented advances in lymphedema treatment can be anticipated in the upcoming years.

Keywords Adipose-derived mesenchymal stem cells / Regenerative medicine / Lymphatic vessels / Lymphedema
Correspondence: Antonio Jorge Forte Division of Plastic Surgery, Mayo Clinic, 4500 San Pablo Rd, Jacksonville, FL 32224, USA

Tel: +1-904-953-2073

Fax: +1-904-953-6489

E-mail: ajvforte@yahoo.com.br

Received: February 7, 2021 • Revised: April 29, $2021 ・$ Accepted: June 16, 2021

pISSN: 2234-6163 • elSSN: 2234-6171 • https://doi.org/10.5999/aps.2021.00339 • Arch Plast Surg 2021;48:559-567

\section{INTRODUCTION}

Secondary lymphedema is a chronic debilitating disease characterized by the accumulation of interstitial fluid due to a disrup- tion of the lymphatic circulation [1]. Radiation and lymphadenectomy related to cancer treatment are the most common causes [2]. A recent meta-analysis demonstrated that one in every five breast cancer patients develops some degree of lymph- 
edema [3]. The risk of lymphedema is particularly higher among those treated with axillary lymph node dissection and regional lymph node irradiation [4]. The diagnosis of lymphedema is usually clinical, identifying discrepancies in volume, shape and skin between limbs [5]. Traditional treatments such as complete decongestive therapy are palliative in their nature and may even impact patient quality of life [6]. Surgical treatment such as lymphovenous anastomosis and lymph node transfer have been used for patients with moderate to severe lymphedema that does not respond to traditional treatment, but it is still considered experimental [7]. This mixed scenario of a highly prevalent but still incurable disease creates a meaningful opportunity for discoveries in regenerative medicine.

Adipose-derived stem cells (ADSCs) are promoting substantial advances in regenerative medicine, which is reflected by the growing number of publications and clinical trials exploring their use $[8,9]$. Recent studies have demonstrated ADSCs capacity to differentiate into lymphatic endothelial cells (LECs) and secrete lymphangiogenic growth factors [10]. It is generally agreed that they are easily extracted, cost-effective, and have few ethical considerations [9]. Nonetheless, the scientific evidence in favor of implementing ADSCs in the clinical routine is still pending [11]. In addition, the scientific community has concerns about its safety profile in oncologic patients [11]. Therefore, we conducted a systematic review of publications exploring the use of ADSCs in lymphatic tissue engineering and regeneration for lymphedema treatment. We hypothesized that ADSCs could regenerate lymphedematous tissue. Current studies appear to support the notion that the use of ADSCs in lymphatic regeneration could help lymphedema patients in the future.

\section{METHODS}

\section{Search strategy}

On July 23, 2019, two reviewers (DB and MTH) independently conducted electronic searches using PubMed/MEDLINE, Cochrane Clinical Answers, Cochrane Central Register of Controlled Trials, and Embase databases, without language or time frame limitations. Disagreements regarding article identification and final selection for inclusion were resolved by another reviewer (AJF). The following were used as either keywords or Medical Subject Headings in all combinations in the search strategy: (((Adipose stem cell) OR Adipose-derived stem cell $))$ AND ((Lymphedema) OR Breast Cancer Lymphedema))). The compiled reference lists were compared and reviewed for potential relevance. The bibliographies of included studies were also examined for articles not acquired through initial search queries. After all reviewers had completed the systematic litera- ture review, additional verification by a medical librarian trained in systematic reviews was requested and received to ensure the most comprehensive review of all published studies meeting these criteria. This study complied with the guidelines outlined in the Preferred Reporting Items for Systematic Reviews and Meta-Analyses (PRISMA).

\section{Selection criteria}

Eligibility criteria included studies reporting data on the use of ADSCs in lymphatic tissue engineering and regeneration. We included studies in vitro, in vivo in animals, and human work. We excluded papers that assessed ADSCs without a direct relationship to lymphatic regeneration (e.g., a paper identifying differences between ADSCs in lymphedema and healthy tissue). $\mathrm{Ab}$ stracts, presentations, correspondence, editorials, and systematic reviews were excluded.

\section{Data extraction and processing}

Extracted data included the year of publication, country, type of study, origin of ADSCs, lymphedema model, additional agents and factors associated with ADSCs in the study, main findings, and conclusions. Data extraction from articles, tables, and figures was performed by two reviewers (DB and MTH), with the accuracy of data entry confirmed by an additional reviewer (AJF).

\section{RESULTS}

\section{Studies characteristics}

Of 22 papers found in the literature, 14 fulfilled the study inclusion criteria (Fig. 1). Authors carried out studies on the use of ADSCs in lymphatic tissue engineering and regeneration in three types of studies: in vitro, in vivo in animals, and human work. Only three studies were clinical, with 11 patients [12-14]. Two mechanisms have been proposed to explain the lymphangiogenic potential of ADSCs: paracrine secretion and direct differentiation (Fig. 2). Authors have also explored mechanisms to enhance the lymphangiogenic potential of ADSCs [15-19]. The strategy most often employed was the enhancement of media used to culture the ADSCs, to which vascular endothelial growth factor (VEGF)-C or interleukin (IL)-7 was added [16,17]. Moreover, it was also proposed cutaneous hydrogel for VEGF$\mathrm{C}$ delivery and viral-mediated transfection for induction of prospero homeobox protein 1 (Prox-1) overexpression or transforming growth factor (TGF)- $\beta 1$ inhibition $[15,16,18]$.

\section{In vitro studies}

In vitro studies have been conducted to determine whether ADSC could be applicable in lymphatic tissue engineering (Table 1, 


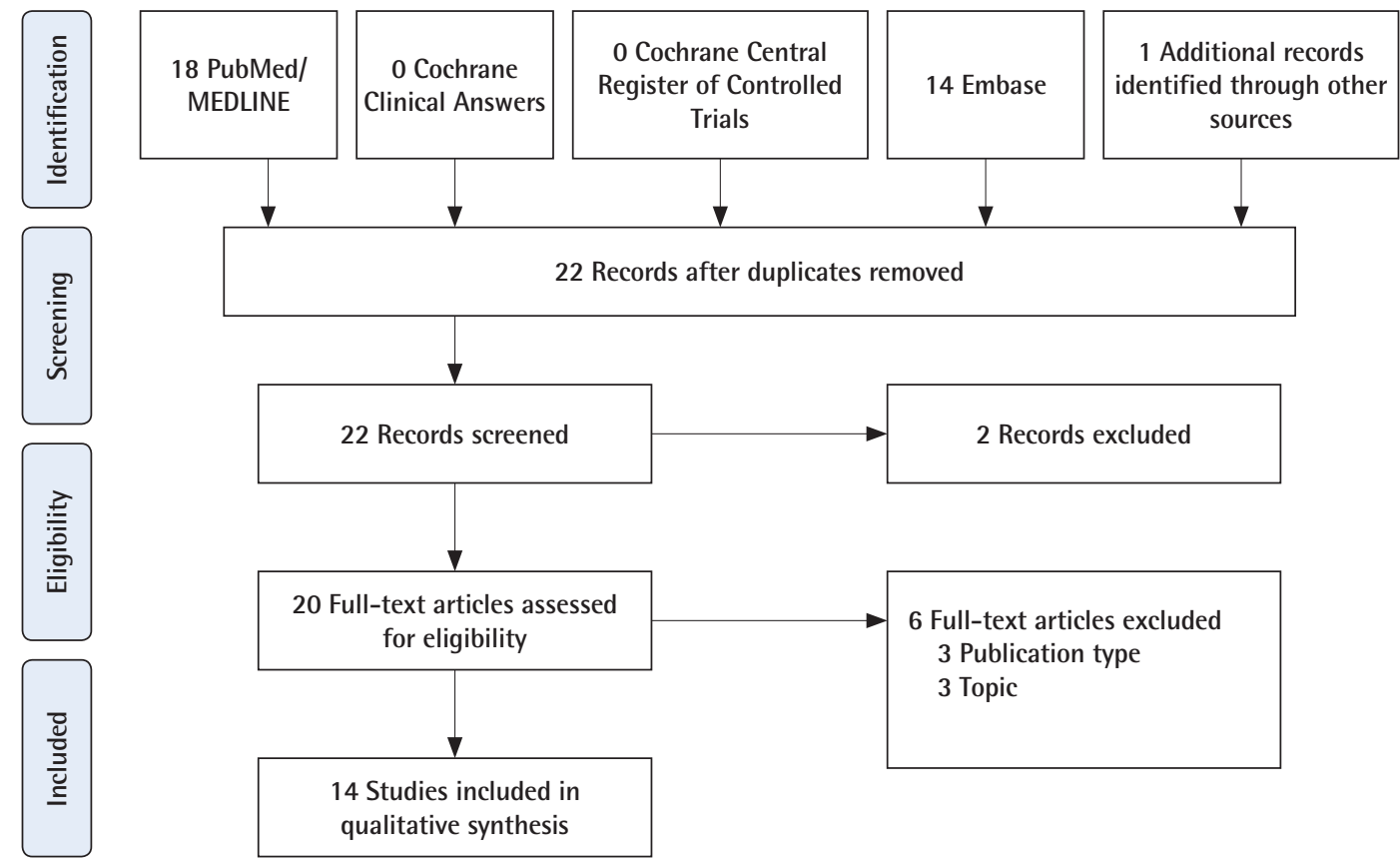

Fig. 1. Flowchart of article identification and final selection. Article identification following Preferred Reporting Items for Systematic Reviews and Meta-Analyses (PRISMA) guidelines.

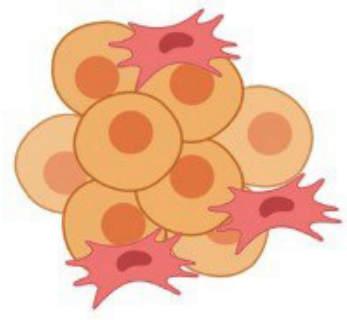

Fat tissue

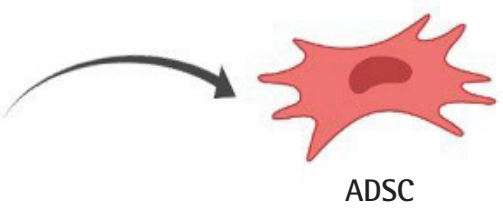

ADSC
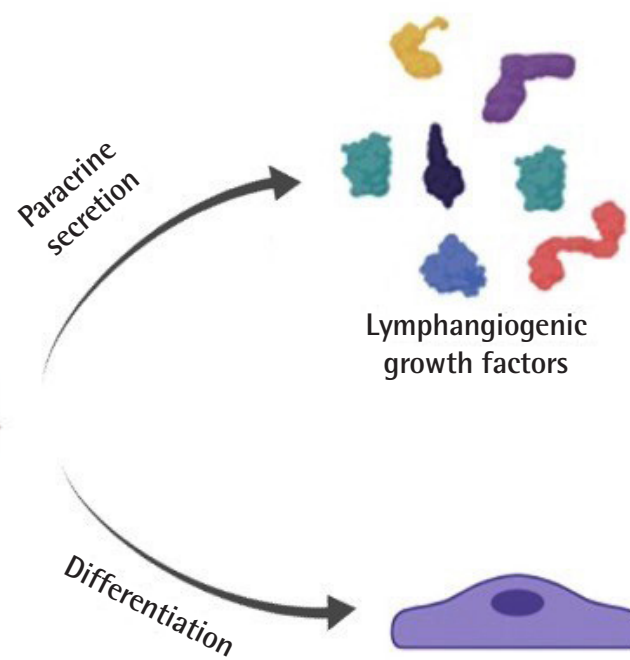

Fig. 2. Proposed Mechanisms for adipose-derived stem cells (ADSCs) lymphangiogenesis. ADSCs have two lymphangiogenesis mechanisms: paracrine secretion and direct differentiation into lymphatic endothelial cells.

Fig. 3). Authors co-cultured LEC and ADSCs to determine if ADSCs have direct effects on LECs in vitro. Strassburg et al. [17] co-cultured human ADSCs and LECs in a proportion of 50:50 cells, demonstrating that ADSCs can induce messenger RNA (mRNA) expression of lymphatic markers and promote lymphatic proliferation and migration. Takeda et al. [20] demonstrated that ADSCs promoted proliferation and migration of LECs, resulting in longer lymphatic tubes than controls. They compared the co-culture of LEC with ADSCs $\left(1 \times 10^{4}\right.$ cells $\left./ \mathrm{cm}^{2}\right)$ or VEGF-C, observing that the increase in lymphangiogenesis by ADSCs is greater than VEGF-C alone $(\mathrm{P}<0.001)$. It was also demonstrated that lymphangiogenic factors from ADSCs were upregulated under serum-starved conditions [20]. Saijo et al. [21] conducted an in vitro study to test the effects of ionizing radiation on dermal LECs co-cultured with human ADSCs. They noticed that factors secreted by ADSCs, such as VEGF-A, VEGF-C, and hepatocyte growth factor, promoted lymphangiogenesis regardless of radiation. Moreover, radiation increased 
Table 1. Summary of in vitro studies

\begin{tabular}{|c|c|c|c|c|c|c|c|}
\hline Author (year) & $\begin{array}{l}\text { ADSCs } \\
\text { origin }\end{array}$ & $\begin{array}{l}\text { Additional } \\
\text { agents }\end{array}$ & Delivery & $\begin{array}{l}\text { Route of } \\
\text { delivery }\end{array}$ & $\begin{array}{l}\text { Lymphangiogenesis } \\
\text { or LE improvement }\end{array}$ & $\begin{array}{l}\text { Paracrine } \\
\text { action }\end{array}$ & $\begin{array}{l}\text { Differentiation } \\
\text { into LEC }\end{array}$ \\
\hline Takeda et al. (2015) [20] & Animal & - & - & - & Yes & Yes & No \\
\hline Strassburg et al. (2016) [17] & Human & VEGF-C & Culture media & - & Yes & Yes & No \\
\hline Deng et al. (2017) [18] & Human & Prox-1 & Virus & - & Yes & Yes & Yes \\
\hline Saijo et al. (2019) [21] & Human & Irradiation & - & Yes & Yes & No & \\
\hline Sun et al. (2019) [19] & Human & $\mathrm{IL}-7$ & Culture media & - & Yes & Yes & Yes \\
\hline Yan et al. (2011) [16] & Animal & $\begin{array}{l}\text { VEGF-C } \\
\text { TGF- } \beta 1 \text { inhibition }\end{array}$ & $\begin{array}{l}\text { Culture media } \\
\text { Virus }\end{array}$ & $\begin{array}{l}\text { Implanted Matrigel } \\
\text { plug }\end{array}$ & Yes & Yes & Yes \\
\hline
\end{tabular}

ADSCs, adipose-derived stem cells; LE, lymphedema; LEC, Iymphatic endothelial cell; VEGF, vascular endothelial growth factor; Prox-1, prospero homeobox protein 1; IL, interleukin; TGF, transforming growth factor.

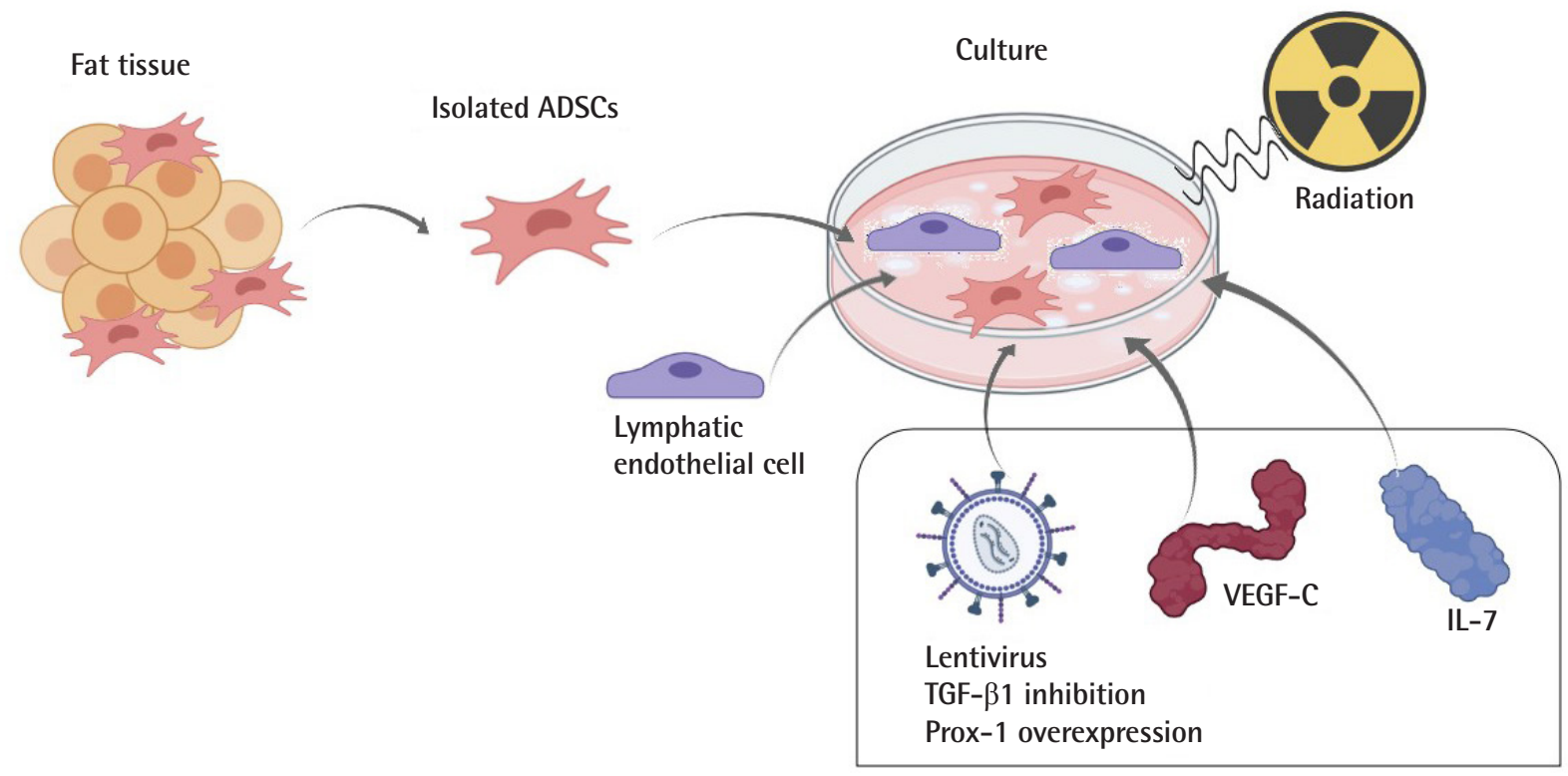

Fig. 3. In vitro studies on the use of adipose-derived stem cells (ADSCs) for lymphatic regeneration. Isolated ADSCs were cultured by authors who investigated different perspectives, such as the impact of co-culturing it with lymphatic endothelial cells, growth factors, and radiation. VEGF, vascular endothelial growth factor; IL, interleukin; TGF, transforming growth factor; Prox-1, prospero homeobox protein 1.

paracrine effects by increasing the expression of fibroblast growth factor in a dose-dependent manner [21].

In 2011, Yan et al. [16] hypothesized that ADSC could promote lymphangiogenesis in response to changes in the balance between pro-and anti-lymphangiogenic cytokines. ADSC harvested from mice $\left(1 \times 10^{6}\right.$ cells $)$ were cultured in a media that was enriched with VEGF-C for 48 hours or that received adenoviral transfection to induce TGF- $\beta 1$ inhibition. They noticed that short term stimulation of ADSCs with VEGF-C increased in vitro expression of Prox-1, VEGF-A, and VEGF-C compared to the control group. Expressed values were notably higher when TGF- $\beta 1$ inhibition was done in combination with VEGFC stimulation [16].

Deng et al. [18] sought to determine if overexpression of Prox1 , induced by transfection of lentiviral vectors, in human $\mathrm{AD}$ SCs could promote differentiation into LECs in vitro. They noticed an increase of LEC-specific markers, pointing out in- creased mRNA and protein levels of podoplanin, lymphatic vessel endothelial hyaluronan receptor 1 (LYVE-1), and VEGF-3. Moreover, tube-like structures were formed by these differentiated ADSCs in the matrix gel [18]. Sun et al. [19] aimed to investigate the effect of IL-7 on ADSC differentiation into LECs. They conducted an in vitro study using human ADSCs $\left(5 \times 10^{5}\right.$ cells) cultured by an induced medium with IL-7. They noticed an increase in RNA and protein levels of LEC markers (Prox-1, LYVE-1, podoplanin, and VEGF-3) in the ADSCs cultured with IL-7 and suggested that this cytokine enhances ADSC differentiation into LECs [19].

\section{In vivo studies in animals}

In vivo studies in animals were conducted on mice models of secondary lymphedema (Table 2, Fig. 4). Shimizu et al. [22] conducted a study to investigate whether the injection of $\mathrm{AD}$ SCs can promote lymphangiogenesis in vivo on a murine tail 
Table 2. Summary of in vivo studies in animals

\begin{tabular}{|c|c|c|c|c|c|c|c|c|c|}
\hline Author (year) & Study & $\begin{array}{l}\text { ADSCs } \\
\text { origin }\end{array}$ & Cultured & $\begin{array}{l}\text { Additional } \\
\text { agents }\end{array}$ & Delivery & $\begin{array}{l}\text { Route of } \\
\text { delivery }\end{array}$ & $\begin{array}{l}\text { Lymphangiogenesis } \\
\text { or LE improvement }\end{array}$ & $\begin{array}{l}\text { Paracrine } \\
\text { action }\end{array}$ & $\begin{array}{l}\text { Differentiation } \\
\text { into LEC }\end{array}$ \\
\hline Yan et al. (2011) [16] & $\begin{array}{l}\text { In vitro and in vivo } \\
\text { animals (mice) }\end{array}$ & Animal & Yes & VEGF-C & $\begin{array}{l}\text { Culture } \\
\text { media }\end{array}$ & $\begin{array}{l}\text { Implanted } \\
\text { Matrigel plug }\end{array}$ & Yes & Yes & Yes \\
\hline Hwang et al. (2011) [15] & $\begin{array}{l}\text { In vivo in animals } \\
\text { (mice) }\end{array}$ & Human & Yes & VEGF-C & $\begin{array}{l}\text { Gelatin } \\
\text { hydrogel }\end{array}$ & Injection & Yes & Yes & Yes \\
\hline Shimizu et al. (2012) [22] & $\begin{array}{l}\text { In vivo in animals } \\
\text { (mice) }\end{array}$ & Animal & No & - & - & Injection & Yes & Yes & No \\
\hline Ackermann et al. (2015) [25] & $\begin{array}{l}\text { In vivo in animals } \\
\text { (mice) }\end{array}$ & Animal & Yes & - & - & Topical & No & Yes & No \\
\hline Yoshida et al. (2015) [23] & $\begin{array}{l}\text { In vivo in animals } \\
\text { (mice) }\end{array}$ & Animal & Yes & - & - & Injection & Yes & Yes & No \\
\hline Hayashida et al. (2017) [24] & $\begin{array}{l}\text { In vivo in animals } \\
\text { (mice) }\end{array}$ & Animal & No & - & - & Injection & Yes & Yes & No \\
\hline
\end{tabular}

ADSCs, adipose-derived stem cells; LE, lymphedema; LEC, Iymphatic endothelial cell; VEGF, vascular endothelial growth factor.

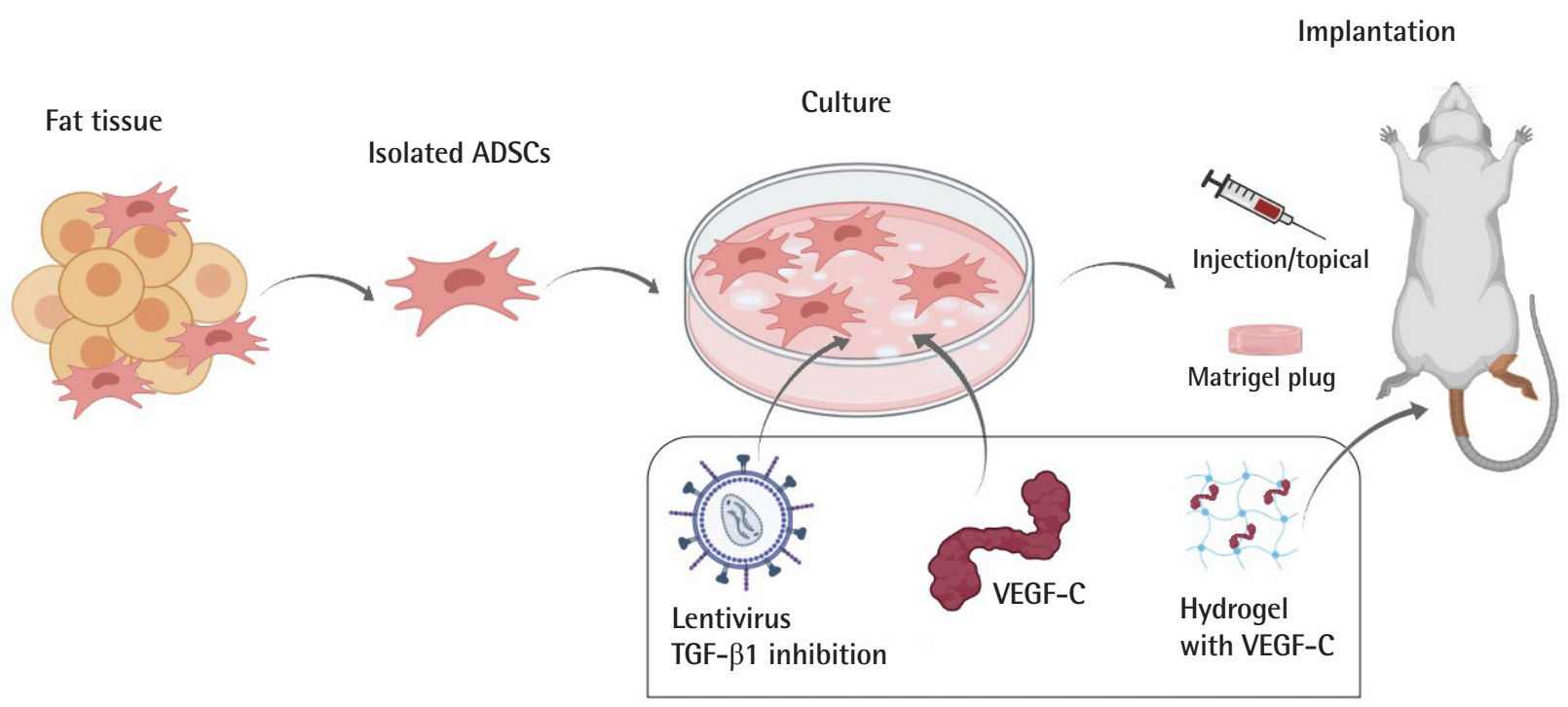

Fig. 4. In vivo animal studies on the use of adipose-derived stem cells (ADSCs) for lymphatic regeneration. Isolated ADSCs were administered to mice after being co-cultured with growth factors. VEGF, vascular endothelial growth factor; TGF, transforming growth factor.

lymphedema model. They implanted $2 \times 10^{6}$ cells of freshly isolated mice ADSC on the first postoperative day of lymphedema induction. Compared to the control group, mice that received an injection of ADSCs presented greater lymphatic capillary density $(\mathrm{P}<0.01)$, tissue expression of VEGF-C $(\mathrm{P}<0.01)$ and plasma levels of VEGF-C $(\mathrm{P}<0.05)$. They proposed that ADSC stimulates lymphangiogenesis through secretion of VEGF-C and recruitment of lymphatic endothelial progenitor cells (marrow-derived M2 macrophages). Yoshida et al. [23] conducted an in vivo study on a murine hindlimb lymphedema model, in which they injected different concentrations of ADSCs (no ADSCs, $1 \times 10^{6}$ cells, $1 \times 10^{5}$ cells, and $1 \times 10^{5}$ cells). They noted an indirect increase in the number of lymphatic vessels measured through cells expressing LYVE-1, VEGF-C, and VEGFR-3. Recovery from circumferential deterioration was significantly higher in the group receiving an injection of a greater amount of
$\operatorname{ADSCs}\left(1 \times 10^{6}\right.$ stem cells $)(\mathrm{P}<0.05)[23]$.

Hayashida et al. [24] conducted an in vivo study on mice to investigate the effect of combining injection of ADSCs $\left(1.0 \times 10^{4}\right.$ cells) with vascularized lymph node transplant, a physiologic surgery to treat lymphedema. They noticed that the injection of ADSCs promoted an increase in lymphatic vessels (LYVE-1 immunoreactivity) and preservation of transplanted lymph nodes $(\mathrm{P}<0.05)$. They were able to prove the function of local lymphatic circulation assessing the lymphatic metastasis' velocity through an injection of B16 melanoma cells. The group treated with ADSCs developed lymph node metastases at a faster rate compared to the control group [24].

Ackermann et al. [25] conducted an in vivo study assessing the lymphangiogenic potential of mice ADSCs and human plateletrich plasma (PRP) separately on a murine tail lymphedema model. PRP, ADSCs $\left(1 \times 10^{5}\right.$ cells $)$, or saline were topically ap- 
Table 3. Summary of clinical studies

\begin{tabular}{|c|c|c|c|c|c|c|}
\hline Author (year) & Cases & ADSCs origin & Cultured & $\begin{array}{l}\text { Additional } \\
\text { agents }\end{array}$ & $\begin{array}{l}\text { Route of } \\
\text { delivery }\end{array}$ & $\begin{array}{l}\text { Lymphangiogenesis } \\
\text { or LE improvement }\end{array}$ \\
\hline Toyserkani et al. (2016) [12] & 1 Patient; follow-up 4 months & Human & No & - & Injection & - \\
\hline Toyserkani et al. (2017) [13] & 10 Patients; follow-up 6 months & Human & No & - & Injection & - \\
\hline Toyserkani et al. (2019) [14] & 10 Patients; follow-up 12 months & Human & No & - & Injection & No \\
\hline
\end{tabular}

ADSCs, adipose-derived stem cells; LE, lymphedema.

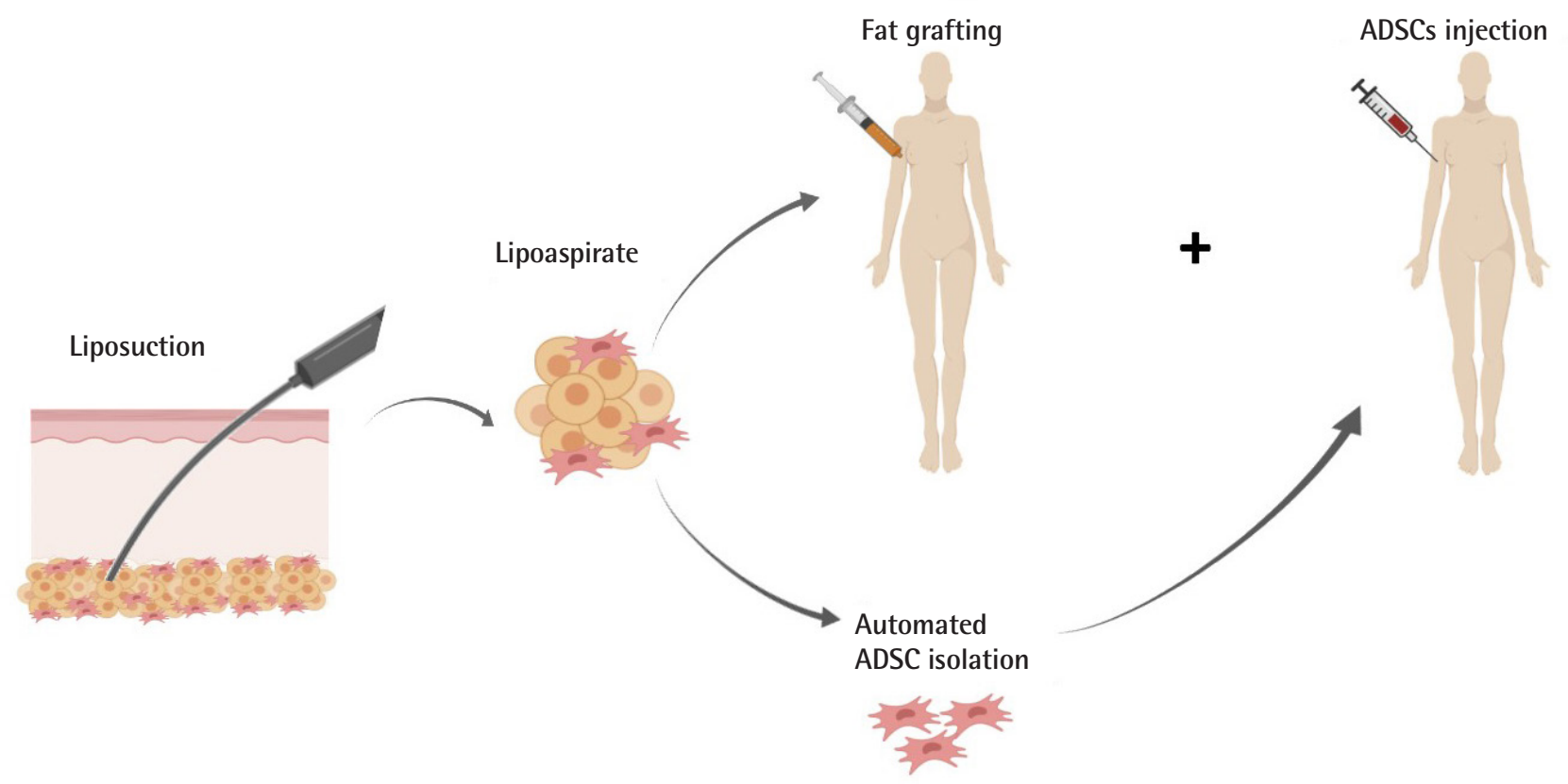

Fig. 5. Clinical studies on the use of adipose-derived stem cells (ADSCs) for lymphatic regeneration. ADSC isolated from lipoaspirate was re-implanted in lymphedema patients.

plied to the wounds. Animals that received PRP or ADSCs presented a faster wound healing. However, regarding lymphangiogenesis, only the administration of PRP demonstrated significant results $(\mathrm{P}<0.01)$. ADSC-treated mice had nearly the same density of lymphatic vessels compared to the control group, and no improvement of lymphedema was seen on day 14 of their experiment. They mentioned that possible explanations for the absence of a lymphangiogenic effect of ADSCs were the short observation period of the study (14 days was not enough to leverage $\mathrm{ADSC}$ antifibrotic potential) and insufficient stimulation of ADSCs by VEGF-C [25].

Enhancement of ADSCs lymphangiogenesis in vivo was an object of consideration by authors. In the same study described above, Yan et al. [16] also conducted an in vivo study in mice using ADSCs that were cultured with VEGF-C or adenoviral transfection for TGF- $\beta 1$ inhibition. Matrigel plug was used to transplant $5 \times 10^{5}$ cells in the animals. They found a significant increase in lymphangiogenic response, the number of proliferating cells, and the number of donor cells for ADSCs cultured with VEGF-C $(\mathrm{P}<0.01)$. Those cells also presented podoplanin, a lymphangiogenic marker, while the cells without stim- ulation did not. This result was also potentiated by TGF- $\beta 1$ inhibition [16]. Hwang et al. [15] aimed to determine if the therapeutic outcomes of human ADSC injection could increase with a topical gelatin hydrogel containing VEGF-C. Murine hindlimb lymphedema model was the choice for their experiment. $\mathrm{AD}$ SCs were implanted at a density of $1 \times 10^{4}$ cells $/ \mathrm{mL}$. Their experiment demonstrated that combined therapy (ADSCs plus VEGF-C hydrogel) had decreased dermal edema and higher lymphatic vessel regeneration compared to VEGF-C or ADSCs only $(\mathrm{P}<0.05)[15]$.

\section{Clinical studies}

A small number of studies from the same group have explored the use of ADSCs for lymphatic regeneration in lymphedema patients (Table 3, Fig. 5). Toyserkani et al. [12-14] published a case report and a series of 10 breast cancer-related lymphedema patients who underwent: liposuction under general anesthesia, intraoperative axillar fat grafting ( $30 \mathrm{~mL}$ of lipoaspirate), and immediate-post-operative axillar injection of freshly isolated ADSCs $\left(5.41 \times 10^{7} \pm 0.97 \times 10^{7}\right.$ cells $)$. A case report of Toyserkani et al. [12] was a 48-year-old woman with breast cancer-re- 
lated lymphedema in her arm who underwent their proposed treatment. They pointed out that, 4 months following the procedure, the patient's lymphedema improved clinically, with a volume reduction of $292 \mathrm{~mL}$ in the affected limb (measured by dual-energy X-ray absorptiometry scan), representing $1 \mathrm{~cm}$ at the wrist/distal arm and $2 \mathrm{~cm}$ at the proximal arm. Moreover, the patient did not experience any adverse effects during the study follow-up time [12].

Toyserkani et al. [13] conducted a pilot study in 10 patients to investigate the feasibility, safety, and efficacy of their treatment. Patients aged between 34 and 68 years had unilateral lymphedema stage I or II, were recurrence-free for a minimum of 1 year, had an American Society of Anesthesiologists status classification score 1 or 2, did not have diabetes mellitus, and were nonsmokers. A scar-releasing fat graft procedure accompanied ADSC injection. At 6 months of follow-up, they noted an improvement in patient-reported outcomes $(\mathrm{P}<0.05)$, and half of the patients $(5 / 10)$ reduced their use of conservative management. However, the overall volume reduction in the affected arm was small and not statistically significant. Therapy was welltolerated, and no significant adverse effects were reported. At 12 months of follow-up, Toyserkani et al. [14] aimed to investigate lymph drainage through quantitative lymphoscintigraphy. They found no differences in the lymphoscintigraphic evaluation and affected arm volume. Although their results were limited due to a small number of patients and lack of control group, their patients presented with absence of any serious adverse events related to ADSC injection [14].

\section{DISCUSSION}

The literature on the pathogenesis and treatment of lymphedema has increased considerably over the years [26-28], but current options for treatment of lymphedema such as physiologic surgeries (lymphaticovenous bypass and lymph node transfer) still have unpredictable outcomes [29]. In this systematic literature review, we have shown the existence of promising evidence supporting the potential of ADSCs in lymphatic tissue engineering and regeneration. However, most of the studies were experimental (in vitro or in vivo on mice). The paracrine capability of ADSCs to secrete lymphangiogenic factors seems well established, but only a small number of publications noticed differentiation of those cells into LECs $[15,16,18,19]$. Studies provided empirical evidence supporting the feasibility to enhance ADSCs lymphangiogenic potential modulating lymphangiogenic cytokines/genes [15-19].

Most studies demonstrated favorable results for the potential use of ADSCs in lymphatic tissue engineering and regeneration.
Ackermann et al. [25] noticed in their experiment that ADSCtreated mice had nearly the same density of lymphatic vessels compared to the control group. One possible explanation was the short follow-up period (14 days), which would not be enough to leverage ADSC antifibrotic potential. However, we noticed that two other studies conducted in similar animals (10-week-old adult male mice) were able to demonstrate the lymphangiogenic potential of ADSCs on day $14[23,24]$. The other explanation given was insufficient stimulation of ADSCs by VEGF-C, which seems more likely. Authors have proposed mechanisms to enhance the lymphangiogenic potential of $\mathrm{AD}$ SCs with promising results using enhanced culture media with VEGF-C or IL-7, cutaneous VEGF-C hydrogel, and viral transfection to increase expression of Prox-1.

Since lymphedema in developing countries is mainly secondary to oncologic surgical procedures, two important concerns of applying this therapy must be discussed. The first is patient safety, since lymphangiogenic growth factors are associated with tumor growth and metastasis [30]. Hayashida et al. [24] noticed in their experimental study that following injection of B16 melanoma cells, the group treated with ADSCs developed lymph node metastases faster than the control group. Although limited conclusions could be drawn through the 12-month-follow-up case series of 10 patients conducted by Toyserkani et al. [14], their study added valuable information regarding the safety of injecting ADSCs in breast cancer patients. The second concern is how well ADSCs could act in the setting of radiation injury (e.g., fibrosis, atrophy, and dry hypovascularized skin with impaired wound healing) [31]. Saijo et al. [21] investigated this, demonstrating that $\mathrm{ADSCs}$ were capable of lymphangiogenesis in vitro regardless of irradiation.

Other therapies have been proposed using non-autologous agents to control tissue inflammation or induce lymphangiogenesis [32]. Lymphangiogenesis has been observed through different mechanisms, mostly non-autologous agents such as anti-inflammatory agents targeting Th2-inflammatory responses and growth factors like VEGF-C $[33,34]$. Compared to them, the main advantage of cell therapies is the fact that they can be extracted from the patient's own body. ADSCs are abundant and can be harvested by liposuction [10]. However, issues still need to be addressed before translating cell therapies to patients, such as determining the appropriate method of isolation and purification, its potential impact on tumor growth, and regulations by the US Food and Drug Administration [9].

We recognize several limitations to our study, common to systematic reviews. There is a potential for bias in interpreting the data reported in each study. Moreover, our search strategy did not include synonyms of ADSCs such as "adipose mesenchymal 
stem cells" or "stromal vascular fraction." Despite these limitations, we feel that our study reports valuable pooled data, particularly regarding the use of ADSCs in lymphatic tissue engineering and regeneration, and proposes ways to enhance it, which can guide future studies to advance the field. Further studies with standardized protocols and long-term outcomes need to be performed to evaluate the effect of ADSCs in the treatment of lymphedema in DMEM (Gibco) supplemented with 2.5 $\mathrm{mg} / \mathrm{mL}$ fungizone (life technologies) and $1 \%$ penicillin/streptomycin and washed several times.

\section{CONCLUSION}

Publications assessing the potential use of ADSCs in lymphatic tissue engineering and regeneration are still limited but demonstrate promising data. There seems to be general agreement that ADSCs could be useful in regenerative lymphangiogenesis and that its effect can be enhanced by adjusting lymphangiogenic cytokines/genes. Unparalleled advances in lymphedema treatment are imminent.

\section{NOTES}

\section{Conflict of interest}

No potential conflict of interest relevant to this article was reported.

\section{Author contribution}

Conceptualization: all authors. Formal analysis: AJ Forte, D Boczar, R Sarabia-Estrada, T Aung, A Quiñones-Hinojosa. Funding acquisition: R Sarabia-Estrada. Methodology: AJ Forte, D Boczar, R Sarabia-Estrada, MT Huayllani, FR Avila, RA Torres, G Guliyeva, T Aung, A Quiñones-Hinojosa. Project administration: AJ Forte, A Quiñones-Hinojosa. Visualization: MT Huayllani, G Guliyeva. Writing - original draft: AJ Forte, D Boczar, MT Huayllani, FR Avila, RA Torres, G Guliyeva, A Quiñones-Hinojosa. Writing - review \& editing: all authors.

\section{ORCID}

Antonio Jorge Forte https://orcid.org/0000-0003-2004-7538 Daniel Boczar https://orcid.org/0000-0002-2037-5331 Rachel Sarabia-Estrada https://orcid.org/0000-0002-6836-5554 Maria T. Huayllani https://orcid.org/0000-0003-2690-1635 Francisco R. Avila https://orcid.org/0000-0001-7856-1367 Alfredo Quiñones-Hinojosa

$$
\text { https://orcid.org/0000-0003-4262-5968 }
$$

\section{REFERENCES}

1. Lawenda BD, Mondry TE, Johnstone PA. Lymphedema: a primer on the identification and management of a chronic condition in oncologic treatment. CA Cancer J Clin 2009; 59:8-24.

2. Basta MN, Wu LC, Kanchwala SK, et al. Reliable prediction of postmastectomy lymphedema: the Risk Assessment Tool Evaluating Lymphedema. Am J Surg 2017;213:1125-33.

3. DiSipio T, Rye S, Newman B, et al. Incidence of unilateral arm lymphoedema after breast cancer: a systematic review and meta-analysis. Lancet Oncol 2013;14:500-15.

4. McDuff SGR, Mina AI, Brunelle CL, et al. Timing of lymphedema after treatment for breast cancer: when are patients most at risk? Int J Radiat Oncol Biol Phys 2019;103: 62-70.

5. Kayiran O, De La Cruz C, Tane K, et al. Lymphedema: from diagnosis to treatment. Turk J Surg 2017;33:51-7.

6. Dayan JH, Ly CL, Kataru RP, et al. Lymphedema: pathogenesis and novel therapies. Annu Rev Med 2018;69:26376.

7. Breastcancer.org. Surgery for lymphedema [Internet]. Ardmore, PA: Breastcancer.org; c2021 [cited 2021 Apr 28]. Available from: https://www.breastcancer.org/treatment/ lymphedema/treatments/surgery.

8. Ceccarelli S, Pontecorvi P, Anastasiadou E, et al. Immunomodulatory effect of adipose-derived stem cells: the cutting edge of clinical application. Front Cell Dev Biol 2020;8:236.

9. Gir P, Oni G, Brown SA, et al. Human adipose stem cells: current clinical applications. Plast Reconstr Surg 2012;129: 1277-90.

10. Toyserkani NM, Christensen ML, Sheikh SP, et al. Stem cells show promising results for lymphoedema treatment: a literature review.J Plast Surg Hand Surg 2015;49:65-71.

11. Toyserkani NM, Jorgensen MG, Tabatabaeifar S, et al. Concise review: a safety assessment of adipose-derived cell therapy in clinical trials. A systematic review of reported adverse events. Stem Cells Transl Med 2017;6:1786-94.

12. Toyserkani NM, Jensen CH, Sheikh SP, et al. Cell-assisted lipotransfer using autologous adipose-derived stromal cells for alleviation of breast cancer-related lymphedema. Stem Cells Transl Med 2016;5:857-9.

13. Toyserkani NM, Jensen CH, Andersen DC, et al. Treatment of breast cancer-related lymphedema with adipose-derived regenerative cells and fat grafts: a feasibility and safety study. Stem Cells Transl Med 2017;6:1666-72.

14. Toyserkani NM, Jensen CH, Tabatabaeifar S, et al. Adiposederived regenerative cells and fat grafting for treating breast 
cancer-related lymphedema: lymphoscintigraphic evaluation with 1 year of follow-up. J Plast Reconstr Aesthet Surg 2019;72:71-7.

15. Hwang JH, Kim IG, Lee JY, et al. Therapeutic lymphangiogenesis using stem cell and VEGF-C hydrogel. Biomaterials 2011;32:4415-23.

16. Yan A, Avraham T, Zampell JC, et al. Adipose-derived stem cells promote lymphangiogenesis in response to VEGF-C stimulation or TGF- $\beta 1$ inhibition. Future Oncol 2011;7:145773.

17. Strassburg S, Torio-Padron N, Finkenzeller G, et al. Adiposederived stem cells support lymphangiogenic parameters in vitro. J Cell Biochem 2016;117:2620-9.

18. Deng J, Dai T, Sun Y, et al. Overexpression of Proxl induces the differentiation of human adipose-derived stem cells into lymphatic endothelial-like cells in vitro. Cell Reprogram 2017;19:54-63.

19. Sun Y, Lu B, Deng J, et al. IL-7 enhances the differentiation of adipose-derived stem cells toward lymphatic endothelial cells through AKT signaling. Cell Biol Int 2019;43:394-401.

20. Takeda K, Sowa Y, Nishino K, et al. Adipose-derived stem cells promote proliferation, migration, and tube formation of lymphatic endothelial cells in vitro by secreting lymphangiogenic factors. Ann Plast Surg 2015;74:728-36.

21. Saijo H, Suzuki K, Yoshimoto H, et al. Paracrine effects of adipose-derived stem cells promote lymphangiogenesis in irradiated lymphatic endothelial cells. Plast Reconstr Surg 2019; 143:1189e-1200e.

22. Shimizu Y, Shibata R, Shintani S, et al. Therapeutic lymphangiogenesis with implantation of adipose-derived regenerative cells. J Am Heart Assoc 2012; 1:e000877.

23. Yoshida S, Hamuy R, Hamada Y, et al. Adipose-derived stem cell transplantation for therapeutic lymphangiogenesis in a mouse secondary lymphedema model. Regen Med 2015; 10:549-62.

24. Hayashida K, Yoshida S, Yoshimoto H, et al. Adipose-derived stem cells and vascularized lymph node transfers suc- cessfully treat mouse hindlimb secondary lymphedema by early reconnection of the lymphatic system and lymphangiogenesis. Plast Reconstr Surg 2017;139:639-51.

25. Ackermann M, Wettstein R, Senaldi C, et al. Impact of platelet rich plasma and adipose stem cells on lymphangiogenesis in a murine tail lymphedema model. Microvasc Res 2015; 102:78-85.

26. Forte AJ, Boczar D, Huayllani MT, et al. Use of autologous blood components in lymphedema treatment: a systematic review. Cureus 2019;11:e5638.

27. Forte AJ, Boczar D, Huayllani MT, et al. Topical approach to delivering targeted therapies in lymphedema treatment: a systematic review. Cureus 2019;11:e6269.

28. Forte AJ, Huayllani MT, Boczar D, et al. Bioimpedance spectroscopy for assessment of breast cancer-related lymphedema: a systematic review. Plast Surg Nurs 2020;40:86-90.

29. Joseph WJ, Aschen S, Ghanta S, et al. Sterile inflammation after lymph node transfer improves lymphatic function and regeneration. Plast Reconstr Surg 2014;134:60-8.

30. Kondo K, Kaneko T, Baba M, et al. VEGF-C and VEGF-A synergistically enhance lymph node metastasis of gastric cancer. Biol Pharm Bull 2007;30:633-7.

31. Wu SH, Shirado T, Mashiko T, et al. Therapeutic effects of human adipose-derived products on impaired wound healing in irradiated tissue. Plast Reconstr Surg 2018;142:38391.

32. Forte AJ, Boczar D, Huayllani MT, et al. Targeted therapies in surgical treatment of lymphedema: a systematic review. Cureus 2019;11:e5397.

33. Zampell JC, Elhadad S, Avraham T, et al. Toll-like receptor deficiency worsens inflammation and lymphedema after lymphatic injury. Am J Physiol Cell Physiol 2012;302: C709-19.

34. Avraham T, Zampell JC, Yan A, et al. Th2 differentiation is necessary for soft tissue fibrosis and lymphatic dysfunction resulting from lymphedema. FASEB J 2013;27:1114-26. 